\title{
REUMATISMO, DOENÇA-DO-TRABALHO
}

\author{
Agenor Lopes Cançado \\ Professor de Medicina Legal na Faculdade de Di- \\ reito de GOIÁS
}

Quando iniciei minha vida de médico, era a sífilis a grande responsável pelas cardiopatias. Hoje, com os modernos métode tratamento e prevenção, ela é flagelo quase ultrapassado e as cardiopatias ligadas ao mal venéreo vêm sendo raridade clínica. $O$ reumatismo e a tripanosomiase de Chagas, são, entre nós, os maiores responsáveis pelas doenças do coração.

0 grande número de invalidados pela moléstia reumatismal e achaques decorrentes, constitui, no momento, séria preocupação da Medicina Social.

Os Institutos de Previdência se vêm sobrecarregados com a assistência a esses doentes, pêso morto reclamando amparo.

0 velho reumatismo articular agudo, tantas vezes deformante, deve ser cosiderado moléstia autônoma e não póde ser confundido com artropatias de outra ordem.

Pelo fato de nem sempre ter localização articular, passou a ser chamado - doença reumatismal; é frequente em todos os meios civilizados e tendo causa infecciosa, não me consta que seu agente específico tenha sido isolado.

Mais frequente no inverno e no outono, não respeita raça, nem sexo e nem mesmo idade.

É um êrro supor que o reumatismo goste dos velhos: crianças e adolescentes são igualmente achacados. 
Dele podem decorrer cardiopatias graves, cuja frequência; no entender de PUGY, é de 66 por 100.

De parte a influência climática e meteorológica, a habitação, o trabalho, o esfôrço são grandes corresponsáveis pelo reumatismo.

A vida industrial contemporânea tem importância considerável na sua gênese e agravação.

0 meio profissional influe sobremodo no determinismo da doença.

Tempelaar e Van Bremer, citados por Rochaix, examinando 3.000 doentes, de reumatismo, verificaram que as maiores vítimas eram encontradas entre os que trabalhavam sob a influência de frequentes oscilações atmosféricas, e principalmente com variações súbitas, termo e higrométricas.

Nas oficinas higiênicas, cujos operários eram protegidos durante o trabalho, os casos de reumatismo rareavam.

Bertarelli considera danosas as indústrias em que, baixas temperaturas, associadas à humidade, concorrem na produção da moléstia reumatismal e das nevrites.

$\mathrm{Na}$ minha longa vida profissional, pude verificar que os homens do campo são mais atacados que os que moram nas cidades.

Vítimas, são, principalmente, os que ficam expostos ao sol durante longas horas, desabrigados, no seu labor agrícola.

Vi mineiros, que trabalham em ambiente quente e úmido, nas profundidades do sólo, em Morro Velho, se invalidarem pelo reumatismo.

Sem dúvida, o desequilíbrio cloro-sódico - consequência da abundante sudação dos mineiros e dos que se expõem ao sól durante longas horas - diminuindo as defesas, predispõe para as infecções.

A exaustão física pela fadiga, com acúmulo de substâncias ponogenas, também é causa predisponente das infecções e, portanto, do reumatismo. 
As grandes siderurgias, onde o operário realiza seu trabalho em alta temperatura, com mudanças frequentes de ambiente, muito quente próximo aos altos fornos, frio e úmido fóra dos locais de trabalho, como acontece na zona montanhosa de Gorcex e Sabará, respondem também pela frequência do reumatismo.

Outro fator que merece referência, pela sua ação, ora intensiva, ora moderada e repetida, é o traumatismo.

Jansen assevera que é enorme o papel do traumatismo na doença reumatismal e destaca a influência das contusões pequenas e repetidas. Dá ao traumatismo a principal culpa nas artites deformantes, tão frequentes entre carregadores de fardo e embarcadiços.

As indústrias bem instaladas, que assistem devidamente aos seus operários fazem construir casas higiênicas, nas proximidades da fábrica, para a habitação dos que colaboram em seu progresso.

Evitam, assim, perda de tempo, despesas com transporte, o risco de acidentes e, sobretudo, previne as infecções.

Já se disse que a tuberculose é doença da habitação. Por ela são responsáveis em grande parte as casas anti-higiênicas, mal instaladas, mal arejadas e de asseio rudimentar.

Também na gênese do reumatismo papel saliente cabe à habitação.

Sobretudo os inglêses, assevera Rochaix, atribuem às más condições da habitação muita culpa no aparecimento das formas crônicas e, mais ainda, nos episódios agudos do reumatismo.

"Miller examinou, sob este aspecto, alunos do Colégio de Éton e crianças da cidade, não internadas, habitando casas cheias de falhas na sua instalação. Nos alunos do Colégio, raros eram os casos de reumatismo. Nos outros a frequência era enorme".

Warner, na população industrial de Cardif e na população rural de Carmarthenshire - influenciadas ambas pelas 
mesmas condições meteorológicas, mas com diferentes condições residenciais, encontrou, entre os operários, 22 por mil de cardiopatia reumatismal e, nos habitantes da cidade, apenas 2 por mil!

Ninguém desconhece a influência das casas mal protegidas no aparecimento das algias articulares.

O barracão dos nossos operários, que tanto vem preocupando aos serviços de assistência social, no Rio e nas outras capitais, tanto responde pela frequência da tuberculose, como pela do reumatismo. Nos maleficios de ordem moral, nem se fala, nem é oportuno falar...

Um bom serviço de Medicina Social pode eliminar de seus quadros o velho reumatismo articular agudo. Afastadas as causas da insalubridade industrial, o calor excessivo, o frio húmido, as mudanças frequentes de temperatura, as más condições de habitação, reduzindo, ao mínimo, as possibilidades e a frequência dos traumatismos, teremos removido os fatores predisponentes da doença e reduzido os invalidados pelo reumatismo, a um pequeno número.

Sem dúvida, o reumatismo é uma das doenças profissionais típicas "de causa crônica, atuando lentamente" de que fala Almeida Júnior, ou "deluida no tempo" no conceitø de Borri.

Suas vítimas são protegidos pela lei, e cabe à perícia precisar quando os patrões, os institutos de previdência e as companhias de seguro lhes devem amparo legal. 